\section{Kidney Blood Pressure Research}

\title{
A Systematic Review and Meta-Analysis of Influenza A Virus Infection During Pregnancy Associated with an Increased Risk for Stillbirth and Low Birth Weight
}

\author{
Jing He $\mathrm{He}^{\mathrm{a}}$ Zhi-Wei Liu ${ }^{\mathrm{a}, \mathrm{f}}$ Yong-Ping Lu ${ }^{\mathrm{a}, \mathrm{c}}$ Tao-Yuan Li ${ }^{\mathrm{a}} \quad$ Xu-Jing Liang \\ Petra C. Arck ${ }^{b}$ Si-Min Huang ${ }^{a}$ Berthold Hocher ${ }^{a, c, d, e} \quad$ You-Peng Chen ${ }^{a}$
}

\begin{abstract}
aDepartment of Infectious Diseases, the first Affiliated Hospital of Jinan University, Guangzhou, China; bLaboratory for Experimental Feto-maternal Medicine, Department of Obstetrics and Fetal Medicine, University Medical Center Hamburg-Eppendorf, Hamburg; 'Institute of Nutritional Science, University of Potsdam, Nuthetal, Potsdam; 'Institut für Laboratoriumsmedizin Berlin (IFLb), Berlin, Germany; eDepartment of Embryology, Medical Faculty, Jinan University, Guangzhou; ' $H$ Huidong County People's Hospital, 516300 Huizhou, Guangdong Province, China
\end{abstract}

\section{Key Words}

Apgar score • Influenza virus • Offspring • Outcome • Pregnancy • Stillbirth • Birth weight

\begin{abstract}
Background/Aims: Impaired pregnancy outcomes, such as low birth weight are associated with increased disease risk in later life, however little is known about the impact of common infectious diseases during pregnancy on birth weight. The study had two aims: a) to investigate risk factors of influenza virus infection during pregnancy, and b) to analyze the impact of influenza virus infection on pregnancy outcome, especially birth weight. Methods: Prospective and retrospective observational studies found in PubMed, MEDLINE, Embase, Google Scholar, and WangFang database were included in this meta analysis. Data of included studies was extracted and analyzed by the RevMan software. Results: Pregnant women with anemia $(P=0.004, \mathrm{RR}=1.46,95 \% \mathrm{CI}: 1.13-1.88)$, obesity $(P<0.00001, \mathrm{RR}=1.35,95 \% \mathrm{CI}: 1.25-1.46)$ and asthma $(P<0.00001, R R=1.99,95 \% \mathrm{CI}: 1.67-2.37)$ had higher rates of influenza virus infection. Regarding birth outcomes, influenza A virus infection did not affect the likelihood for cesarean section. Mothers with influenza had a higher rate of stillbirth $(P=0.04, \mathrm{RR}=2.36,95 \% \mathrm{CI}: 1.05$ 5.31), and their offspring had low 5-minute APGR Scores $(P=0.009, R R=1.39,95 \%$ CI: 1.08 1.79). Furthermore, the rate for birth weight $<2500 \mathrm{~g}(P=0.04, \mathrm{RR}=1.71,95 \% \mathrm{CI}: 1.03-2.84)$ was increased. Conclusion: Results of this study showed that anemia, asthma and obesity during pregnancy are risk factors influenza A virus infection during pregnancy. Moreover, gestational influenza A infection impairs pregnancy outcomes and increases the risk for low birth weight, a known risk factor for later life disease susceptibility.




\section{Kidney Blood Pressure Research}

\section{Introduction}

An influenza outbreak was first described based on clinical symptoms in 1580 [1]. It transmitted from Asia to Africa, and ended in Europe. The first documented pandemic influenza outbreak with influenza virus type A H1N1 in 1918 was called the Spanish flu, since it originated from Spain [2]. In recent years, the latest influenza A (H1N1) pandemic outbreak was in 2009. After the first case has been reported in Mexico in April 2009, the influenza infection cases increased very fast within a very short time-period. In merely 17 months, influenza virus spread across the entire world [3]. From April 2009 to August 2010 , due to the influenza virus infection $[4,5]$, there were nearly 200 million influenza A virus infections reported. About 250,000 to 500,000 of these infected individuals died. Although compared with the influenza pandemic in 1918, 1957 and 1968, the morbidity and mortality of the pandemic influenza A (H1N1) in 2009 were less pronounced, it was still a huge worldwide problem for the health care systems. In particular elderly people and young children were heavily affected, because their immune system was either not fully functional anymore or simply immature. Another group with a particular high risk of suffering from influenza A virus infection are pregnant women. The underlying reasons are, however, yet unknown.

Gil Mor et al [6] summarized that current patho-physiological understanding of influenza A virus infection in pregnancy in their review. During pregnancy there is a physiological shift of cytokines that on the one hand enable tolerance of the foreign tissue - the fetus - by the mother. This shift in the immune tolerance on the other hand also alters the response of the mother to infections such as influenza A. Beside the mother the fetus may also be infected via the placenta. Not much is known yet, whether influenza A virus infection during pregnancy affects birth outcomes, such as birth weight. In a magnitude of studies it was demonstrated that reductions in birth weight are not just associated with short term consequences but can impact on later life disease susceptibility. The developmental origins of health and disease hypothesis states that suboptimal conditions in early life permanently alter the phenotype of the offspring that are responsible for this increased adult disease risk [7-12]. We conducted this systematic review to better understand clinical risk factors for influenza A virus infection and its impact on maternal and fetal outcomes.

We were particularly interested if influenza A virus infection affects birth weight, since low birth weight is a risk factor for later life disease susceptibility.

\section{Materials and Methods}

\section{Search strategy}

Two investigators screened published data in PubMed, MEDLINE, Embase, Google Scholar and WangFang Database using the MeSH terms such as pregnancy, gravidity, pregnant women, mother, maternal, and/or neonatal, embryo, fetus, and influenza, influenza virus from January 1, 1989 to January 18, 2017. All records, i.e. relevant reviews, case reports and papers were screened in both English and Chinese. Articles written in other languages were excluded (Figure 1).

\section{Inclusion and exclusion criteria}

Prospective studies or retrospective clinical observational studies were included. Case reports or studies describing interventions of any type, for instance pharmacological interventions were excluded. All included papers had to provide information about how influenza A (H1N1) virus infection was diagnosed. The studies needed to compare maternal risk factors for influenza virus type A infection in affected and non-affected pregnant women. Baseline demographic data in the study cohort had to be provided. Analysis in terms of potential influenza virus infection related outcomes should have been described. Studies about other types of influenza, such as seasonal influenza, influenza virus type B or avian influenza virus were also excluded. Also studies which included other conditions besides influenza A were excluded. 


\section{Kidney Blood Pressure Research}

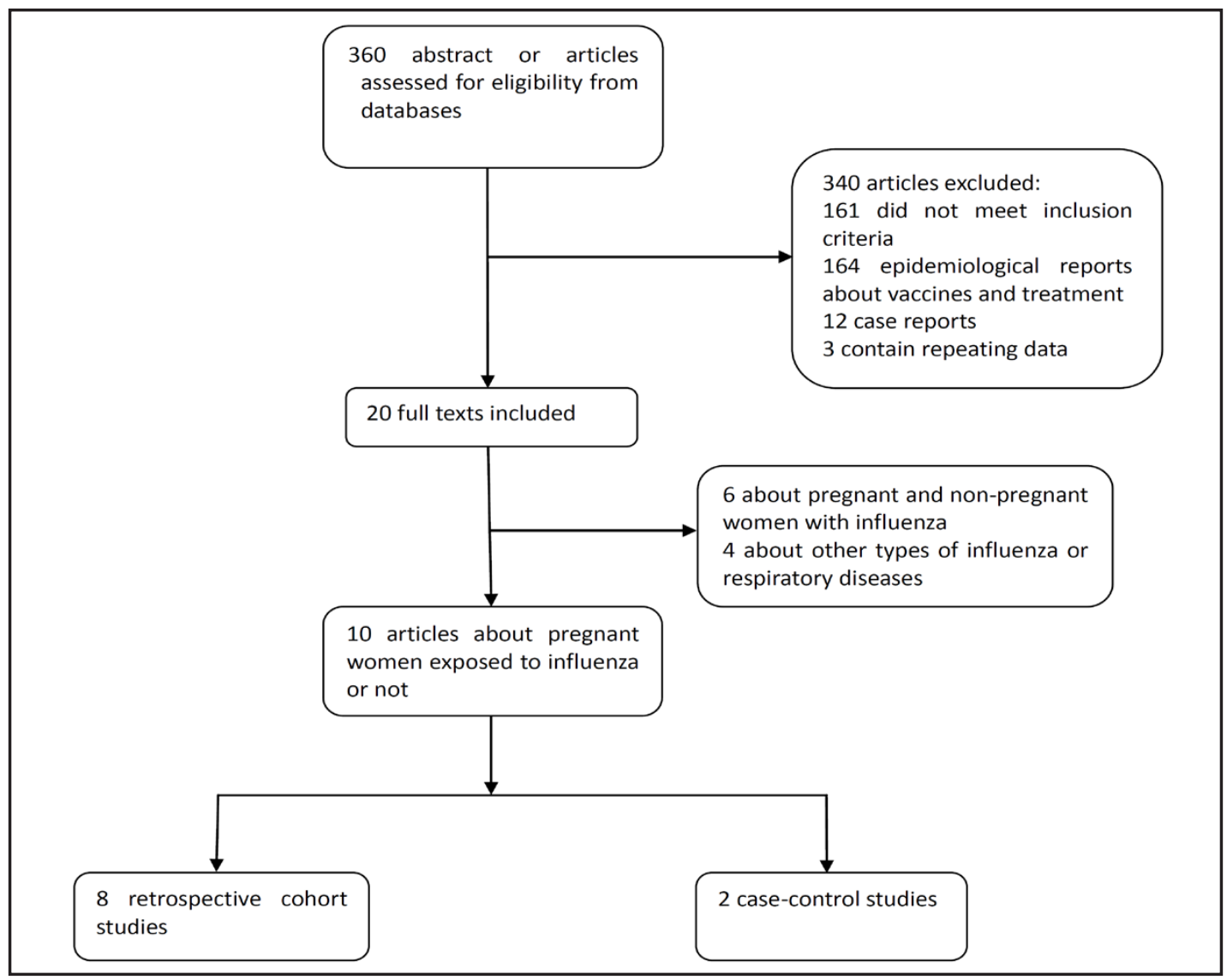

Fig. 1. Flow chart of searching article, eliminating the unmatched articles and include articles. The articles were searched in PubMed, MEDLINE, Embase, Google Scholar and WangFang Database from January 1, 1989 to January 18, 2017. Articles were excluded, if the trials did not meet the inclusion criteria or data were reported incomplete.

\section{Quality assessment of included articles}

Two authors carefully read the full text and evaluated the article quality by the Newcastle-Ottawa Scale (NOS) standards [13]. The papers were analyzed and ranked by a point system according to three categories:

Selection and definition of the study population. In the included trials, the diagnosis of influenza had to be defined either by typical clinical symptoms assessed by experienced physicians, serological tests (a fourfold rise of antibodies titers) or real-time polymerase chain reaction (RT-PCR). Cases with influenza A virus infection were targets of this study, so cases with other types of influenza virus infection were excluded [14-17].

Comparability of cases and controls based on design of the study. Studies were required to be comparable. According to how many confounding factors were considered studies were given one point (study controlled one confounding factor) or two points (study controlled for two or more confounding factors). Regarding the assessment of outcome studies had to provide clinical data covering the whole period from infection to complete recovery and received one point in the scoring if they did so.

Scoring criteria for cohort study and case-control study. For cohort studies, if the cases in the study were follow-up, it will get one point. If the follow-up was long enough to the end of disease, the article will get two points. If the follow up was long enough and reported the missing cases at the end of the study, it will get three points. For case-control studies, if the exposed fact of case group was confirmed by reliable 


\section{Kidney \\ Blood Pressure Research}

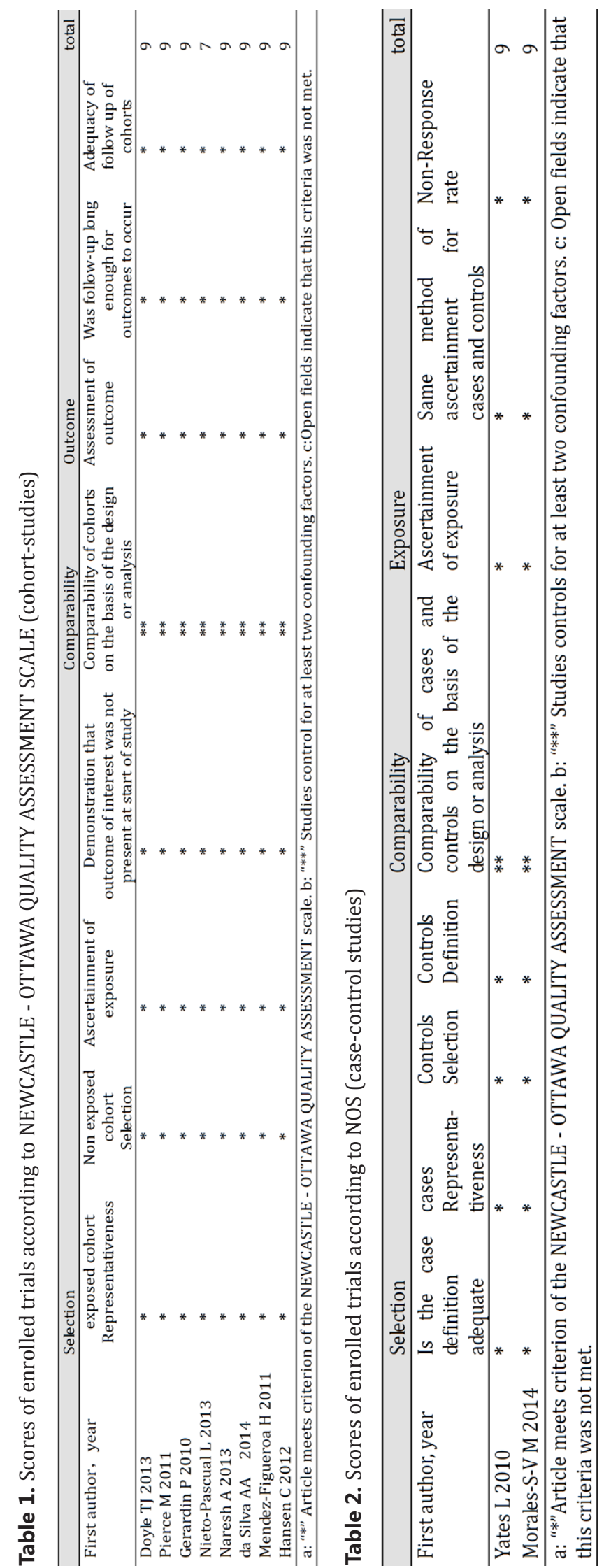

Kidney Blood Press Res 2017;42:232-243

\begin{tabular}{l|l}
\hline DOI: 10.1159/000477221 & (C) 2017 The Author(s). Published by S. Karger AG, Basel
\end{tabular}

Published online: March 12, $2017 \quad$ www.karger.com/kbr medical records or structured blinding research, the study will get one point. Then, if exposed fact of case group and control group in a study was confirmed by the same method, the study will get two points. If a study satisfied previous two conditions and reported the nonresponse rate, it will get three points.

To analyze a reasonable outcome, the articles with scores lower than or equal to six were eliminated. If there were inconclusive or doubtful data reported, we tried to get the original data and used these data for the analysis.

\section{Data extraction and analysis}

Clinical data, such as maternal smoking, maternal preexisting asthma, maternal diabetes, maternal obesity/ overweight, maternal anemia, delivery modes, fetal stillbirth, preterm birth, low birth weight, and Apgar scores of neonates from the exposure group and the control group were extracted. The data was analyzed by the Review Manager Version 5.0 (Rev-Man 5.0) software as recently described [18]. The reliable test for overall effect was set as $P<0.05$. If there was no significant heterogeneity $\left(\mathrm{I}^{2} \leq 50, P>0.1\right)$, the fixeffects model (Matel-Haenszel method) was used. If there was evidence of relevant heterogeneity $\left(\mathrm{I}^{2}>50, P<0.1\right)$, factors that caused heterogeneity were identified and tried to explain.

As a result, appreciate subgroup analysis can be used to explain the heterogeneity. The random-effects model (Inverse Variance method) was used, if the heterogeneity was above 50 .

\section{Results}

Quality of included articles (Table 1 and Table 2)

Ten articles that compared between pregnant women with influenza A (H1N1) virus infection and those without infection were included to our study. There were 


\section{Kidney Blood Pressure Research}

Table 3. Maternal basic information provided by the eligible enrolled studies

\begin{tabular}{|c|c|c|c|c|c|c|c|}
\hline First author, year & $\begin{array}{l}\text { Pregnant } \\
\text { women with } \\
\text { influenza: } \\
\text { normal }\end{array}$ & $\begin{array}{l}\text { Obesity or } \\
\text { Overweight }\end{array}$ & Smoking & $\begin{array}{l}\text { Asthma } \\
\text { before } \\
\text { delivery }\end{array}$ & Diabetes & Anemia & Cesarean \\
\hline Doyle T J 2013 & $187: 295747$ & $46: 56194$ & & & & & 92(191):115060(300398) \\
\hline Pierce M 2011 & $256: 1220$ & $63: 202$ & $59: 257$ & & & & $100: 299$ \\
\hline Gerardin P 2010 & $139: 440$ & $67: 186$ & $27: 56$ & 16:- & $7: 30(445)$ & & $21: 68(445)$ \\
\hline Nieto-Pascual L 2013 & $76: 92$ & $0: 2$ & $18: 20$ & $1: 3$ & $3: 4$ & & $18: 21$ \\
\hline Naresh A 2013 & $142: 710$ & & $13: 72$ & $25: 71$ & $9: 38$ & $17(115): 86$ & $36: 206$ \\
\hline Yates L 2010 & $241: 1223$ & $58: 202$ & $55: 258$ & $32: 66$ & & & \\
\hline Morales-S -V M 2014 & $51: 114$ & $12: 10$ & $11: 19$ & $6: 11$ & $2: 4$ & & \\
\hline da Silva A A 2014 & $163: 46$ & & & & & & $106: 32$ \\
\hline Mendez-Figueroa H 2011 & $14: 25$ & & & & $0: 1$ & & $1: 7$ \\
\hline Hansen C 2012 & $887: 100576$ & $264: 22132$ & & $72: 3966$ & $124: 13223$ & $40: 2901$ & $304: 33036$ \\
\hline Events total & & $510: 78928$ & $183: 682$ & $136: 4117$ & $145: 13300$ & $57: 2987$ & $678: 148729$ \\
\hline total & & $1837: 399412$ & $905: 3799$ & $1397: 102715$ & $1308: 102059$ & 1002:101286 & $1939: 410621$ \\
\hline
\end{tabular}

Table 4. Descriptive data of studied patients provided by the eligible enrolled studies

\begin{tabular}{|c|c|c|c|c|c|c|}
\hline First author, year & $\begin{array}{l}\text { Pregnant women } \\
\text { with influenza: } \\
\text { normal }\end{array}$ & Preterm Labor & $\begin{array}{l}<2500 \mathrm{~g} \\
\text { infant }\end{array}$ & $\begin{array}{l}\text { Small } \\
\text { gestational } \\
\text { age(SGA) }\end{array}$ & Stillbirth & $\begin{array}{l}\text { 5-minute } \\
\text { Apgar Scores }\end{array}$ \\
\hline Doyle T J 2013 & 191:300398 & $45: 31259$ & $30: 25998$ & & & $34: 31848$ \\
\hline Pierce M 2011 & $256: 1220$ & $59: 89$ & $50: 94$ & & $7: 7$ & \\
\hline Gerardin P 2010 & $142: 440$ & $22(139): 38(445)$ & & $14: 42$ & $0(139): 5(445)$ & $4: 22$ \\
\hline Nieto-Pascual L 2013 & $75: 89$ & $3: 9$ & & $11: 13$ & $1: 1$ & \\
\hline Naresh A 2013 & 142:710 & $21: 82$ & & $12: 52$ & & \\
\hline Yates L 2010 & $241: 1223$ & & & & & \\
\hline Morales-S-V M 2014 & $51: 114$ & & & & & \\
\hline da Silva A A 2014 & $163: 46$ & $38: 15$ & & & $5: 0$ & \\
\hline Mendez-Figueroa H 2011 & $15: 25$ & & & & & $9: 9$ \\
\hline Hansen C 2012 & $981: 109796$ & 108:10224 & 69:6931 & $72: 7943$ & & $10: 988$ \\
\hline events total & & $296: 41716$ & 149:33023 & $109: 8050$ & $13: 13$ & $57: 32867$ \\
\hline total & & $1947: 412704$ & $1428: 411414$ & $1340: 110980$ & $633: 1803$ & $1329: 410659$ \\
\hline
\end{tabular}

2,156 pregnant women with influenza A virus infection and 400,193 pregnant women without influenza as control. The Newcastle-Ottawa Scale was used to evaluate the quality of the studies. Table 1 and 2 showed how the studies were scored.

\section{Basic information (Table 3 and Table 4)}

Eleven complications or risk factors were analyzed. Diabetes, asthma, anemia, obesity, smoking, and cesarean section were maternal related items. Preterm Birth, small for gestational age (SGA), birth weight $<2500 \mathrm{~g}$, stillbirth, and 5-minute APGAR Scores were analyzed for neonates.

Most studies were calculated the number of mothers who accepted cesarean delivery, but Doyle's study [19] had the number of babies born from cesarean delivery. For the delivery mode, the exposed cohort numbers were 191 cases in cesarean section, and the control were 300,398 cases in Doyle's study [19]. In Gerardin's [20] study, as well as Doyle's study [19], for the control cohort there were 445 cases in cesarean section. In addition, some information about mothers or babies was lost in other studies, so the total numbers of the samples may be different from the real situation. These were likewise the cases in Naresh's study [21] about Anemia and Gerardin's study [20] about preterm labor and stillbirth.

\section{Maternal outcome}

All included trials described risk factors for influenza A virus infection during pregnancy. We analyzed five possible risk factors for influenza A virus infection during pregnancy as follows:

Obesity. According to the new diagnosis of obesity as a chronic disease [22], obesity was defined as BMI $\geq 30 \mathrm{~kg} / \mathrm{m}^{2}$, overweight was defined as $25<\mathrm{BMI} \leq 29.9 \mathrm{~kg} / \mathrm{m}^{2}$. We established 


\section{Kidney Blood Pressure Research}

\begin{tabular}{|c|c|c|c|c|c|c|c|c|}
\hline \multirow[b]{2}{*}{ Study or Subqroup } & \multicolumn{2}{|c|}{ Experimental } & \multicolumn{2}{|c|}{ Control } & \multirow{2}{*}{ Weight } & Risk Ratio & \multirow{2}{*}{\multicolumn{2}{|c|}{$\begin{array}{c}\text { Risk Ratio } \\
\text { M-H, Fixed, } 95 \% \mathrm{Cl}\end{array}$}} \\
\hline & Events & Total & Events & Total & & M-H, Fixed, 95\% Cl & & \\
\hline \multicolumn{9}{|l|}{ 5.1.1 obesity } \\
\hline Doyle T J 2013 & 46 & 187 & 56194 & 295747 & $10.3 \%$ & $1.29[1.01,1.66]$ & & - \\
\hline Hansen C 2012 & 264 & 887 & 22132 & 100576 & $55.9 \%$ & $1.35[1.22,1.50]$ & & $\square$ \\
\hline Morales-S-V M 2014 & 12 & 51 & 10 & 114 & $0.9 \%$ & $2.68[1.24,5.80]$ & & \\
\hline Nieto-Pascual L 2013 & 0 & 76 & 2 & 92 & $0.3 \%$ & $0.24[0.01,4.96]$ & & \\
\hline Pierce M 2011 & 63 & 256 & 202 & 1220 & $10.1 \%$ & $1.49[1.16,1.91]$ & & $\rightarrow$ \\
\hline Yates L 2010 & 58 & 241 & 202 & 1223 & $9.6 \%$ & $1.46[1.13,1.88]$ & & $\rightarrow$ \\
\hline Subtotal $(95 \% \mathrm{Cl})$ & & 1698 & & 398972 & $87.1 \%$ & $1.38[1.27,1.50]$ & & 1 \\
\hline Total events & 443 & & 78742 & & & & & \\
\hline \multicolumn{9}{|c|}{ Heterogeneity: $\mathrm{Chi}^{2}=5.04, \mathrm{df}=5(\mathrm{P}=0.41) ; \mathrm{i}^{2}=1 \%$} \\
\hline \multicolumn{9}{|c|}{ Test for overall effect: $Z=7.65$ ( $P<0.00001)$} \\
\hline \multicolumn{9}{|l|}{ 5.1.2 overweight/obesity } \\
\hline Gerardin P 2010 & 67 & 139 & 186 & 440 & $12.9 \%$ & $1.14[0.93,1.40]$ & & 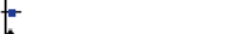 \\
\hline Subtotal $(95 \% \mathrm{Cl})$ & & 139 & & 440 & $12.9 \%$ & $1.14[0.93,1.40]$ & & 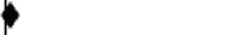 \\
\hline Total events & 67 & & 186 & & & & & \\
\hline \multicolumn{9}{|c|}{ Heterogeneity: Not applicable } \\
\hline \multicolumn{9}{|c|}{ Test for overall effect: $Z=1.26(P=0.21)$} \\
\hline Total $(95 \% \mathrm{Cl})$ & & 1837 & & 399412 & $100.0 \%$ & $1.35[1.25,1.46]$ & & 4 \\
\hline Total events & 510 & & 78928 & & & & & \\
\hline \multicolumn{7}{|c|}{ Heterogeneity: $\mathrm{Chi}^{2}=7.95, \mathrm{df}=6(\mathrm{P}=0.24) ; \mathrm{I}^{2}=24 \%$} & & $1 \quad 10 \quad 100$ \\
\hline \multicolumn{7}{|c|}{ Test for overall effect: $Z=7.66(P<0.00001)$} & ${ }_{\text {Favours [experimental] }}^{0.01}$ & 1 Favours [control] \\
\hline
\end{tabular}

Fig. 2. Obesity was defended as BMI $\geq 30 \mathrm{~kg} / \mathrm{m}^{2}$ [23]. Pregnant women with influenza virus infection were compared to pregnant women without influenza virus infection considering body weight (normal body weight, overweight or obesity).

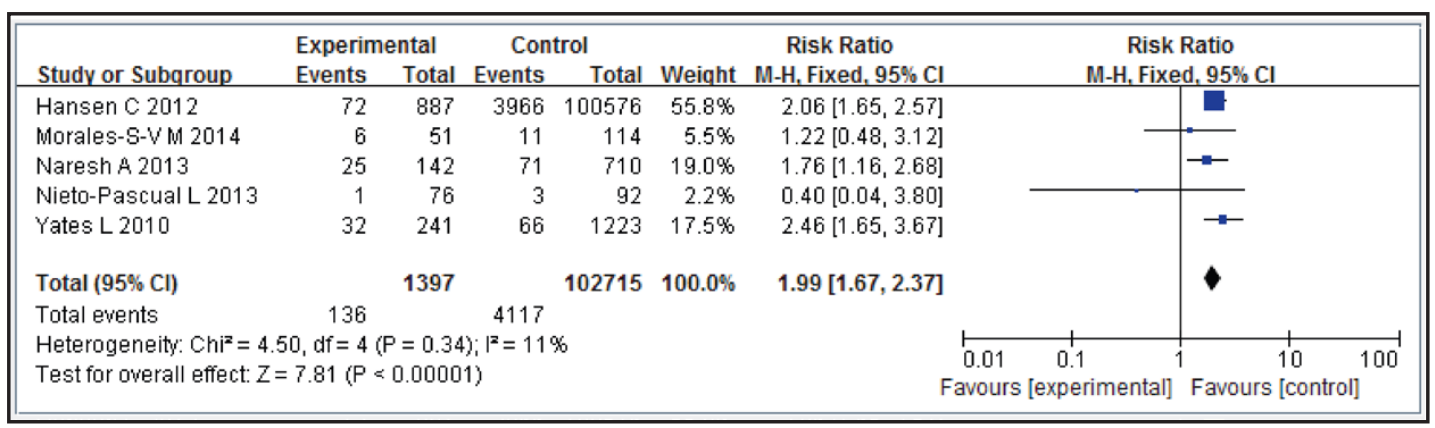

Fig. 3. Pregnant women with influenza virus infection were compared to pregnant women without influenza virus infection according to preexisting asthma.

two groups: "obesity" and "overweight/obesity". The analysis revealed that obesity is a risk factors for influenza virus infection in pregnant women $(P<0.00001, \mathrm{RR}=1.35,95 \% \mathrm{CI}$ : 1.251.46) (Figure 2).

Smoking. Six studies [20, 21, 23-25, 27] provided maternal smoking data. According to the time of smoking, the outcome was divided in three groups: smoking before pregnancy, but quit during pregnancy [23]; smoking both before and during pregnancy [21, 24, 25, 27]; and not specified [20]. The result showed that maternal smoking does not increase influenza $A$ virus infection risk $\left(P=0.11, \mathrm{RR}=1.13,95 \% \mathrm{CI}: 0.97-1.31, \mathrm{I}^{2}: 0 \%\right)$.

Asthma. Five studies [21, 23, 24, 26, 27] gave complete maternal asthma data (Figure 3). Maternal asthma was demonstrated to increase the risk of acquiring influenza A virus infection during pregnancy $(P<0.00001, \mathrm{RR}=1.99,95 \% \mathrm{CI}$ : 1.67-2.37). 


\section{Kidney Blood Pressure Research}

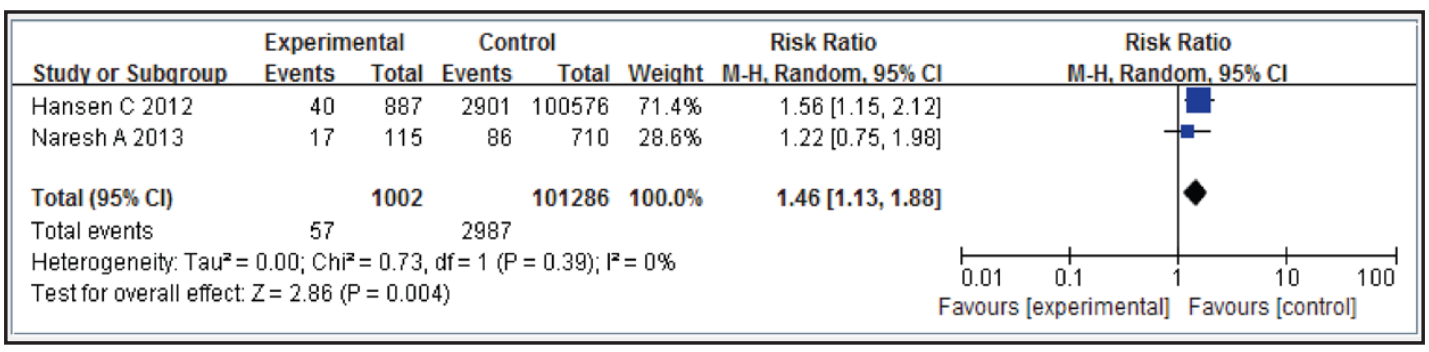

Fig. 4. Pregnant women with influenza virus infection were compared to pregnant women without influenza virus infection with respect to anemia during pregnancy.

Diabetes. Six studies $[20,21,24,26-28]$ in this meta-analysis included data regarding diabetes. According to the time of diagnosis, these outcomes were divided into three groups: diabetes mellitus before pregnancy (DM), gestational diabetes (GDM) and DM/GDM. The test for an overall effect was insignificant $(P=0.49)$. The subgroups analysis demonstrated that pregnant women with DM before pregnancy $(P=0.68)$ and GDM $(P=0.87)$ were not associated with a higher risk of influenza A virus infection during pregnancy.

Anemia. If a pregnant woman had a hematocrit $<33 \%$ or hemoglobin concentrations $<110 \mathrm{~g} / \mathrm{L}$, she was categorized as having anemia [30]. According to the Rev-Men 5.2 analysis, anemia during pregnancy was a risk factor for getting influenza A virus infection $(P=0.004$, $\mathrm{RR}=1.46,95 \%$ CI: 1.13-1.88) (Figure4) .

Besides, some studies suggest that the mode of delivery might be affected by maternal influenza A virus infection. Hence, we gathered data from eight studies [19-21, 25-29]. There was no statistical significant association between influenza $A$ virus infection and cesarean section $(P=0.28, \mathrm{RR}=1.10,95 \% \mathrm{CI}: 0.93-1.30)$ and the heterogeneity existed ( $\mathrm{chi}^{2}=27.44$, $\left.\mathrm{I}^{2}=74 \%\right)$. The non-contemporary comparison bias appeared in studies of Doyle's and Pierce's $[19,25]$ for they enrolled the control groups in different periods.

\section{Neonatal outcome}

Ten studies have described neonatal outcomes. We summarized them in regards to four adverse neonatal outcomes as follows:

Preterm birth. Preterm birth was defined as being born before 37 weeks of gestation. A test for an overall effect was $P=0.08$ (RR=1.45, 95\% CI: 0.96-2.18, $\left.\mathrm{I}^{2}=89 \%\right)$. We did not find an association between maternal influenza $A$ virus infection and preterm birth.

Low birth weight. Low birth weight was defined as birth weight below 2500g. Offspring born to pregnant women with influenza A had a higher risk of low birth weight $(P=0.04$, $\left.\mathrm{RR}=1.71,95 \% \mathrm{CI}: 1.03-2.84, \mathrm{I}^{2}=89 \%\right)$. The cases included only during influenza pandemic period, but the control included from pre-pandemic period in Doyle's study [19] and Pierce's study [25]. So the heterogeneity (89\%) in this meta-analysis came from time inconsistency between case and control group (Figure 5).

SGA was not associated with influenza A virus infection during pregnancy $(P=0.83$, $\mathrm{RR}=1.02,95 \%$ CI: $\left.0.84-1.23, \mathrm{I}^{2}=0 \%\right)$.

Stillbirth. Influenza A virus infection was associated with nearly 2.4 times more stillbirths than the control $(P=0.04, \mathrm{RR}=2.36,95 \% \mathrm{CI}$ : 1.05-5.31). Results of this study demonstrated an association between influenza A virus infection during pregnancy and stillbirth (Figure 6). 


\section{Kidney Blood Pressure Research}

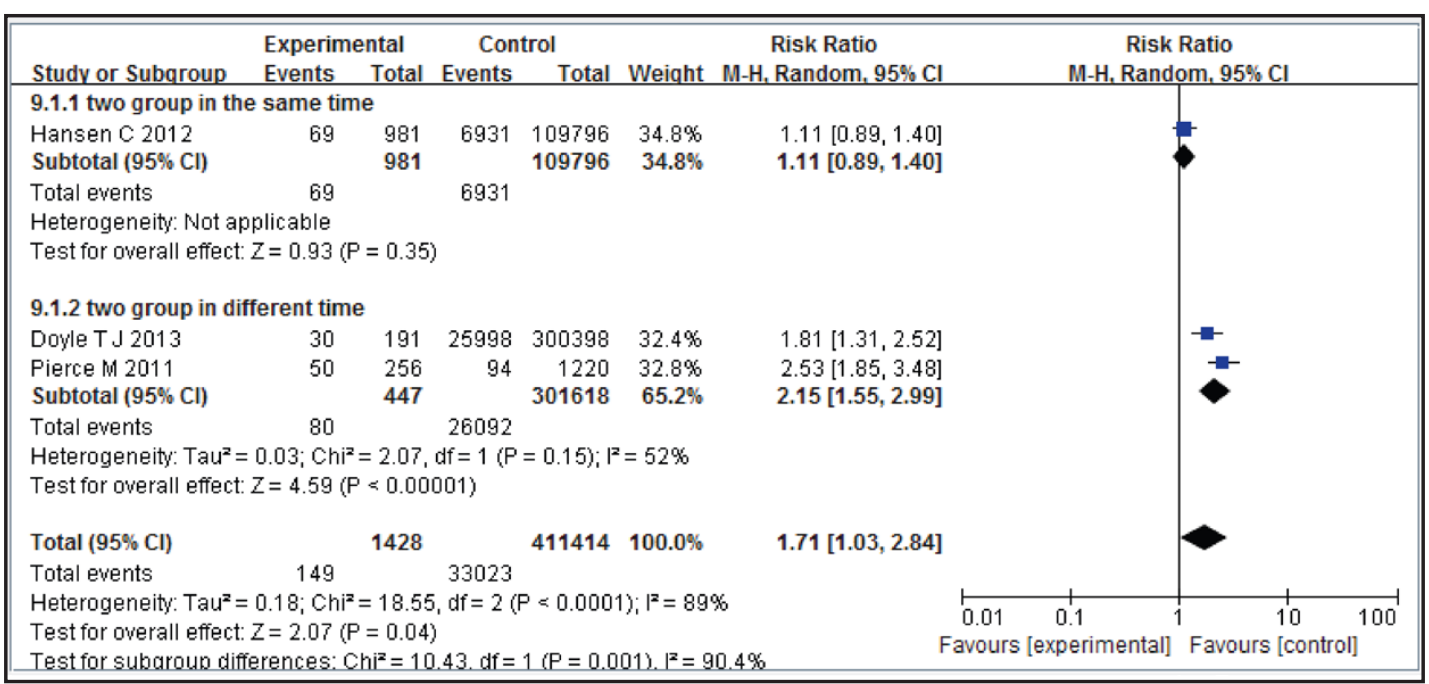

Fig. 5. Pregnant women with influenza virus infection were compared to pregnant women without influenza virus infection with respect to low birth weight of their offspring. Low birth weight infant was defended as infant with birth weight $<2500 \mathrm{~g}$.

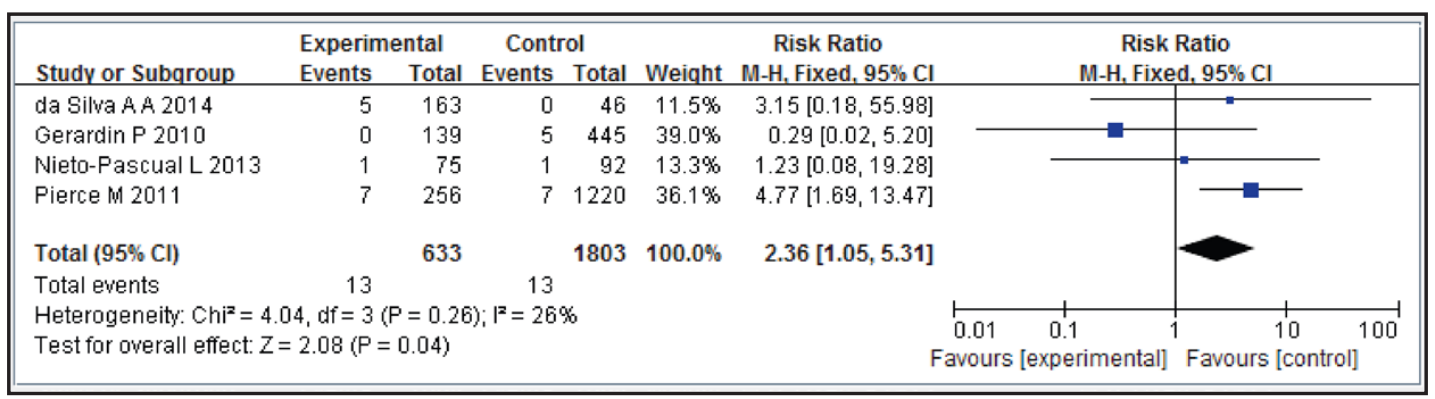

Fig. 6. Pregnant women with influenza virus infection were compared to pregnant women without influenza virus infection with respect to the occurrence of stillbirth cases.

5-Minute APGAR Scores. APGAR score was used to assess the health condition of the newborn. Maternal influenza A virus infection was associated with lower APGAR scores at 5 minutes $(P=0.009, \mathrm{RR}=1.39,95 \% \mathrm{CI}: 1.08-1.79)$ compared to not infected mothers. Most of the neonates may get $<9$ scores at 5 minutes after born $(P=0.001, \mathrm{RR}=1.53,95 \%$ CI: 1.181.98). The heterogeneity appeared (40\%), because Gerardin's study [20] calculated neonates with very low APGAR scores (APGAR scores <7) (Figure 7).

\section{Discussion}

This meta-analysis demonstrated that pregnant women with anemia, obesity, and asthma had higher risk of influenza A virus infection. Mothers with influenza A virus infection had a higher risk of stillbirth, and offspring of the mothers with influenza A virus infection had low birth weight or/and low APGR Scores at 5 minutes postpartum. Smoking and diabetes mellitus before pregnancy were not associated with higher influenza A virus infection rate during pregnancy. Influenza A virus infection did not affect the likelihood for cesarean section, preterm birth, or small for gestational age babies. The current study thus provides evidence that - beside classical risk factors for low birth weight - influence A virus infection during pregnancy represents another factor associated with low birth weight that might impact later life disease susceptibility. 


\section{Kidney Blood Pressure Research}

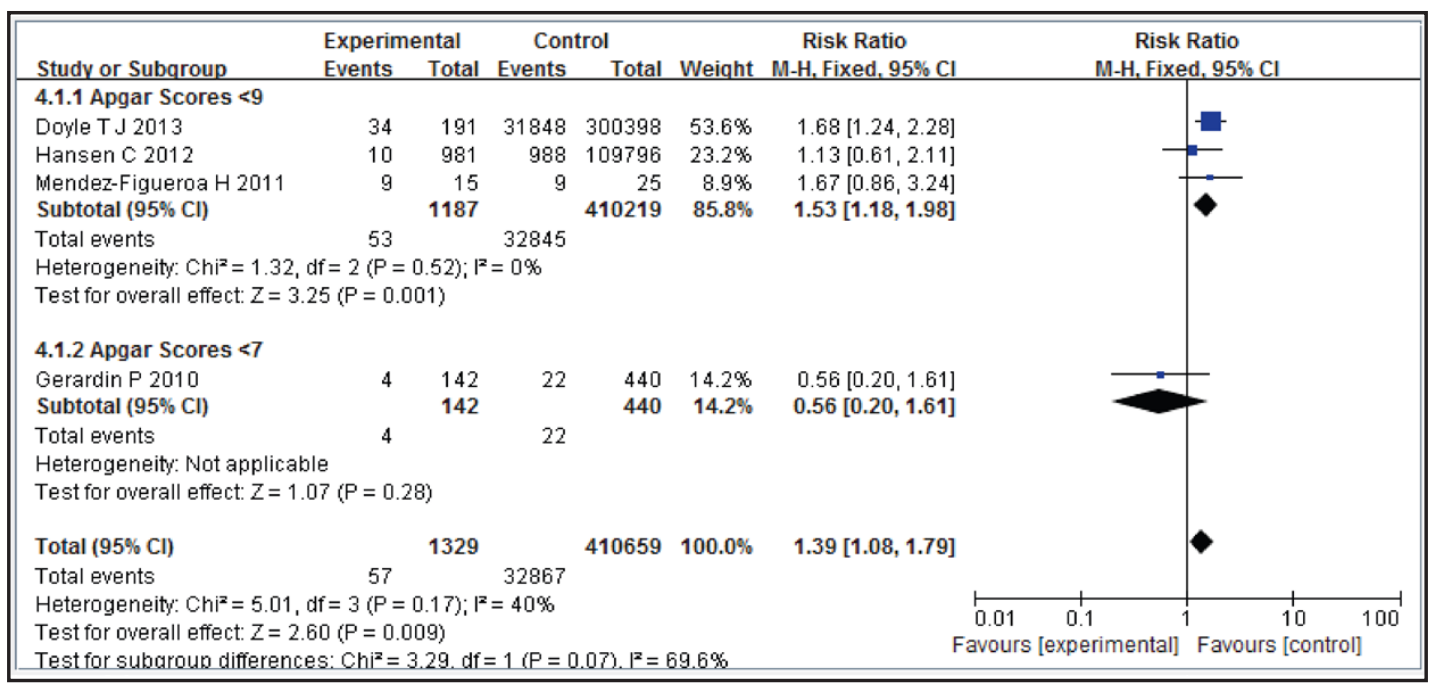

Fig. 7. Pregnant women with influenza virus infection were compared to pregnant women without influenza virus infection with regard to low Apgar Scores as outcome. A low APGAR score was defended as APGAR score 8 and below. We also analyzed cases with very low APGAR score = asphyxia (definition: APGAR score $<7)$ as outcome parameter.

Anemia, obesity, and asthma were identified as independent risk factors for influenza A virus infection during pregnancy. Louie JK likewise reported that pregnant women with influenza virus infection have a higher prevalence of asthma [31]. A study which observed H1N1 infection from April to September 2009 in Canada found pregnant women were hospitalized more frequently than the non-pregnant women, and preexisting lung disease or asthma increased the mortality risk of influenza A virus infection [32]. A Danish included more than 100,000 pregnant women during 7 years, and it was found that offspring of pregnant women with asthma have an increased risk of influenza A virus infection (HR=1.34; 95\% CI: 1.23-1.46) [33].

Two included studies $[21,26]$ reported numbers of pregnant women with anemia during influenza A (H1N1) epidemic. Although they didn't give the details of patients' disease, it was revealed that anemia during pregnancy can be a risk for getting influenza A virus (H1N1) infection. However, more clinical data are needed to better assess the association between anemia and influenza virus infection.

Our results demonstrated that pregnant women who were overweight or obese had an increased risk for influenza A (H1N1) infection. As well as young adults, BMI $>25 \mathrm{~kg} / \mathrm{m}^{2}$ was an increased risk for having influenza infection. If overweight or obesity adults infected with influenza A virus (H1N1), 75\% of them may suffer from hypoxemia [34].

Diabetes before and during pregnancy was not associated with an increased risk for influenza virus infection during pregnancy. Contrary to our findings, a study by An JH et al. [35], showed that pregnant women who suffered influenza A virus H1N1 infection during the 2009 outbreak in Korea had a higher prevalence for GDM as compared to controls. This difference to our data might be related to the different inclusion criteria used in the study of An JH et al. [35], were only patients that had to be referred to the ICU were considered, but not out-patients as it was done in our study.

Influenza A virus infection during pregnancy was an independent risk factor for stillbirth and offspring with low birth weight or/and low APGR Scores at 5 minutes in our meta-analysis. Pregnancy complicated by influenza A virus infection can increase the risk of stillbirth which has been reported already for the "Spanish" influenza pandemic from 1918 to 1919 . The risk of stillbirth was estimated to be increased by approximately $30 \%$ in a study performed in Osaka, Japan [36]. 


\section{Kidney Blood Pressure Research}

Furthermore, results of our study showed that influenza A virus infection during pregnancy is associated with an increased risk to give birth to low birth weight neonates. A study by the Center for Disease Control (CDC) in USA analyzing influenza infections in pregnant women from April 2009 to October 2010 came to similar results [37]. Pregnancy with severe influenza virus infection - that required hospitalization was associated with a higher rate of low birth weight (43.8\%) and higher rates of preterm birth $(63.6 \%)$ as compared to non-affected control cases $(8.2 \%$ low birth weight; $12.3 \%$ preterm birth) [37]. Different from the CDC study, preterm birth was not associated with influenza A virus infection during pregnancy in our study. It may be due to 4 of 7 studies about preterm birth didn't report or analyze birth weight of babies. Only 3 studies were included in the Metaanalyze of low birth weight babies.

A low APGAR score predicts both the association with asphyxia of the neonates and the occurrence of HIE (Hypoxic Ischemic Encephalopathy) and IVH (Intraventricular hemorrhage) later on [38]. If the newborns get APGAR scores $<7$, they will be asphyxia. Our data did not show that the incidence rate of maternal influenza A virus infection is high in newborns with an APGAR score below 7, this finding is most likely due to the overall small number of cases in this subgroup of neonates in our study. Analyzing the entire study population, on the other hand, clearly indicated that maternal influenza A virus infections are associated with overall lower APPAR scores at birth. It indicated that pregnancy with influenza A virus infection could increase case numbers of offspring's slight hypoxia. The offspring can recover from hypoxia easily, if they can be dealt with timely. Doctors or nurses should pay more attention to these offspring because they have more chance to be asphyxia.

The current meta-analysis has limitations. Due to the preceding defined screening strategies, we did not detect birth defects as outcome. Luteijn et al. [39], however, demonstrated a medium to strong association between first trimester influenza exposure and congenital abnormalities such as neural tube defects, anencephaly, encephalocele, spina bifida and hydrocephaly in their meta-analysis. Our screening approach was also limited to original articles in English and Chinese, hence studies published in German, Russian or Japanese language for example were not considered. Moreover, drugs taken by patients were confounding factors to our analysis results unavoidably.

\section{Conclusion}

Our meta-analysis revealed that asthma, anemia, and overweight/obesity are risk factors for getting influenza A virus infection during pregnancy, while diabete before or during pregnany was not associated with a higher risk of infection. Maternal influenza A virus infection during pregnancy was shown to increase the risk of stillbirth, and offspring with lower 5-minute APGAR score. Our study did not observe an association between influenza A virus infection and preterm birth. Importantly, results of our study showed an association between gestational influenza A virus infection and low birth weight. Low birth weight is associated with an increased disease susceptibility in later life. The current study emphases that besides classical factors that can impact on later life disease risk in terms of the developmental origins hypothesis, also influenza A virus infection during pregnancy might be a relevant factor in this regards. In this context, it is important to note that the risk of gestational influenza A virus infection is preventable by a simple vaccination.

\section{Disclosure Statement}

All authors declare that there is no conflict of interest. 


\section{Kidney \\ Blood Pressure Research}

$\mathrm{He} / \mathrm{Liu} / \mathrm{Lu}$ et al.: Influenza During Pregnancy Increases Risk for Stillbirth and Low Birth Weight

\section{Acknowledgements}

The study is supported by Guangzhou City Technology Scientific Research Program (No. 201510010027), Science and Technology Planning Project of Guangdong Province (No. 2014A020212220), and Jinan University Special Fund for High Level University Construction Medical Team (No. 88016013046).

\section{References}

1 Macnalty AS: A History of Epidemics in Britain// A history of epidemics in Britain. Univ Press 1965:639.

2 Billings M: The Influenza Pandemic of 1918. June, 1997 modified RDS February, 2005. Available from: URL: http://virus.stanford.edu/uda/ (accessed on April 26th 2017).

3 WHO: Evolution of a pandemic A (H1N1) 2009, April 2009 - March 2010. Printed in Switzerland. Available from: URL: http://apps.who.int/iris/bitstream/10665/44394/1/9789241599924_eng.pdf (accessed on April 26th 2017).

4 Doshi P: The 2009 influenza pandemic. Lancet infect Dis 2013;13:193.

5 Girard MP, Tam JS, Assossou OM, Kieny MP: The 2009 A (H1N1) influenza virus pandemic: A review. Vaccine 2010;28:4895-4902.

6 Mor G, Cardenas I: The immune system in pregnancy: a unique complexity. Am J Reprod Immunol 2010;63:425-433.

-7 Reichetzeder C, Dwi Putra SE, Li J, Hocher B: Developmental Origins of Disease - Crisis Precipitates Change. Cell Physiol Biochem 2016;39:919-938.

-8 Li J, Tsuprykov 0, Yang X, Hocher B: Paternal programming of offspring cardiometabolic diseases in later life. J Hypertens 2016;34:2111-2126.

-9 Hocher B, Haumann H, Rahnenführera J, Reichetzeder C, Kalk P, Pfab T, Tsuprykov O, Winter S, Hofmann U, Li J, Püschel GP,Lang F, Schuppan D, Schwab M, Schaeffeler E: Maternal eNOS Deficiency Determines a Fatty Liver Phenotype of the Offspring in a Sex Dependent Manner. Epigenetics 2016;11:539-552.

$>10$ Li J, Lu YP, Reichetzeder C, Kalk P, Kleuser B, Adamski J, Hocher B: Maternal PCaaC38:6 is Associated With Preterm Birth - a Risk Factor for Early and Late Adverse Outcome of the Offspring. Kidney Blood Press Res 2016;41:250-257.

11 Li J, Chen Y P, Dong Y P, Yu CH., Lu YP, Xiao XM, Hocher B: The impact of umbilical blood flow regulation on fetal development differs in diabetic and non-diabetic pregnancy. Kidney Blood Press Res 2014;39:369377.

-12 Reichetzeder C, Chen H, Föller M, Slowinski T, Li J, Chen YP, Lang F, Hocher B: Maternal vitamin D deficiency and fetal programming--lessons learned from humans and mice. Kidney Blood Press Res 2014;39:315-329.

13 Stang A: Critical evaluation of the Newcastle-Ottawa Scale for the assessment of the quality of nonrandomized studies in meta-analyses. Eur J Epidemiol 2010;25:603-605.

14 Neuzil KM, Reed GW, Mitchel EF, Simonsen L, Griffin MR: Impact of influenza on acute cardiopulmonary hospitalizations in pregnant women. Am J Epidemiol 1998;148:1094-1102.

-15 Rogers VL, Sheffield JS, Roberts SW, McIntire DD, Luby JP, Trevino S, Wendel GD Jr: Presentation of seasonal influenza A in pregnancy: 2003-2004 influenza season. Obstet Gynecol 2010;115:924-929.

-16 Irving WL, James DK, Stephenson T, Laing P, Jameson C, Oxford JS, Chakraverty P, Brown DW, Boon AC, Zambon MC: Influenza virus infection in the second and third trimesters of pregnancy: a clinical and seroepidemiological study. BJOG 2000;107:1282-1289.

17 Ács N, Bánhidy F, Puhó E, Czeizel AE: Pregnancy complications and delivery outcomes of pregnant women with influenza. J Matern Fetal Neonatal Med 2006;19:135-140.

-18 Lu YP, Tsuprykov O, Vignonzellweger N, Heiden S, Hocher B: Global Overexpression of ET-1 Decreases Blood Pressure - A Systematic Review and Meta-Analysis of ET-1 Transgenic Mice. Kidney Blood Press Res 2016;41:770-780.

19 Doyle TJ, Goodin K, Hamilton JJ: Maternal and Neonatal Outcomes among Pregnant Women with 2009 Pandemic Influenza A (H1N1) Illness in Florida, 2009-2010: A Population-Based Cohort Study. PloS One 2013;8:e79040.

20 Gerardin P, El Amrani R, Cyrille B, Gabrièle M, Guillermin P, Boukerrou M, Boumahni B, Randrianaivo H, Winer A, Rouanet JF, Bohrer M, Jaffar-Bandjee MC, Robillard PY, Barau G, Michault A: Low clinical burden 


\section{Kidney \\ Blood Pressure Research}

$\mathrm{He} / \mathrm{Liu} / \mathrm{Lu}$ et al.: Influenza During Pregnancy Increases Risk for Stillbirth and Low Birth Weight

of 2009 pandemic influenza A (H1N1) infection during pregnancy on the island of La Reunion. PloS one 2010;5:e10896.

-21 Naresh A, Fisher BM, Hoppe KK, Catov J, Xu J, Hart J, Lynch AM, Gibbs R, Eschenbach D, Gravett M, Beigi $\mathrm{RH}$ : A multicenter cohort study of pregnancy outcomes among women with laboratory-confirmed H1N1 influenza. J Perinatol 2013;33:939-943.

-22 Garvey WT, Garber AJ, Mechanick JI, Bray GA, Dagogo-Jack S, Einhorn D, Grunberger G, Handelsman Y, Hennekens CH, Hurley DL, McGill J, Palumbo P, Umpierrez G; The Aace Obesity Scientific Committee: American association of clinical endocrinologists and american college of endocrinology position statement on the 2014 advanced framework for a new diagnosis of obesity as a chronic disease. Endocr Pract 2014;20:977-989.

-23 Yates L, Pierce M, Stephens S, Mill AC, Spark P, Kurinczuk JJ, Valappil M, Brocklehurst P, Thomas SH, Knight M: Influenza A/H1N1v in pregnancy: an investigation of the characteristics and management of affected women and the relationship to pregnancy outcomes for mother and infant. Health Technol Assess 2010;14:109-182.

24 Morales-Suárez-Varela M, González-Candelas F, Astray J, Alonso J, Castro A, Cantón R, Galán JC, Garin O, Soldevila N, Baricot M, Castilla J, Godoy P, Delgado-Rodríguez M, Martín V, Mayoral JM, Pumarola T, Quintana JM, Tamames S, Llopis-González A, Domínguez A; CIBERESP Cases and Controls in Pandemic Influenza Working Group, Spain: Pandemic Influenza A (H1N1) in Non-vaccinated, Pregnant Women in Spain (2009-2010). Matern Child Health J 2014;18:1454-1461.

25 Pierce M, Kurinczuk JJ, Spark P, Brocklehurst P, Knight M; UKOSS: Perinatal outcomes after maternal 2009/ H1N1 infection: national cohort study. BMJ 2011;342:d3214.

26 Hansen C, Desai S, Bredfeldt C, Cheetham C, Gallagher M, Li DK, Raebel MA, Riedlinger K, Shay DK, Thompson M, Davis RL: A large, population-based study of 2009 pandemic Influenza A virus subtype H1N1 infection diagnosis during pregnancy and outcomes for mothers and neonates. J Infect Dis 2012;206:12601268.

-27 Nieto-Pascual L, Arjona-Berral JE, Marín-Martín EM, Muñoz-Gomariz E, Ilich I, Castelo-Branco C: Early prophylactic treatment in pregnant women during the 2009-2010 H1N1 pandemic: obstetric and neonatal outcomes. J Obstet Gynaecol 2013;33:128-134.

28 Mendez-Figueroa H, Raker C, Anderson BL: Neonatal characteristics and outcomes of pregnancies complicated by influenza infection during the 2009 pandemic. Am J Obstet Gynecol 2011;204:S58-S63.

29 da Silva AA, Ranieri TM, Torres FD, Vianna FS, Paniz GR, Sanseverino PB, Picon PD, de Azevedo PB, Costa MH, Schuler-Faccini L,Sanseverino MT: Impact on pregnancies in south Brazil from the influenza A (H1N1) pandemic: cohort study. PloS one 2014;9:e88624.

30 WHO: Iron deficiency anaemia: assessment prevention and control. A guide for programme managers. Geneva Switzerland 2001. Available from: URL: http://apps.who.int/iris/bitstream/10665/66914/1/ WHO_NHD_01.3.pdf?ua=1 (accessed on April 26th 2017).

-31 Louie JK, Acosta M, Jamieson DJ, Honein MA, California Pandemic (H1N1) Working Group: Severe 2009 H1N1 influenza in pregnant and postpartum women in California. N Engl J Med 2010;65:227-228.

-32 Campbell A, Rodin R, Kropp R, Mao Y, Hong Z, Vachon J, Spika J, Pelletier L: Risk of severe outcomes among patients admitted to hospital with pandemic (H1N1) influenza. CMAJ 2010;182:349-355.

-33 Tegethoff M, Olsen J, Schaffner E, Meinlschmidt G: Asthma during pregnancy and clinical outcomes in offspring: a national cohort study. Pediatrics 2013;132:483-491.

34 Bijani B, Pahlevan AA, Qasemibarqi R, Jahanihashemi H: Metabolic syndrome as an independent risk factor of hypoxaemia in influenza A (H1N1) 2009 pandemic. Infez Med 2016;24:123-130.

35 An JH, Kim HN, Choi OJ, Kim GS, Kim UJ, Jang MO, Kang SJ, Park KH, Jung SI, Kwon YS, Jang HC: Was 2009 Pandemic Influenza A (H1N1) Mild Among Pregnant Korean Women? Chonnam Med J 2013;49:96-99.

-36 Nishiura H: Excess risk of stillbirth during the 1918-1920 influenza pandemic in Japan. Eur J Obstet Gynecol Reprod Biol 2009;147:115.

37 Centers for Disease Control and Prevention (CDC): Maternal and infant outcomes among severely ill pregnant and postpartum women with 2009 pandemic influenza A (H1N1)-United States, April 2009-August 2010. Morb Mortal Wkly Rep 2011;60:1193-1196.

-38 Dalili H, Nili F, Sheikh M, Hardani AK, Shariat M, Nayeri F: Comparison of the four proposed apgar scoring systems in the assessment of birth asphyxia and adverse early neurologic outcomes. PloS One 2015;10:e0122116.

39 Luteijn JM, Brown MJ, Dolk H: Influenza and congenital anomalies: a systematic review and meta-analysis. Hum Reprod 2014;29:809-823. 